\title{
SOME ASPECTS REGARDING THE IMPACT OF FOREIGN DIRECT INVESTMENT IN ECONOMIC DEVELOPMENT
}

\author{
Florina Popa \\ Academia Română, Institutul de Economie Națională, București, \\ florinapopa289@gmail.com
}

\begin{abstract}
Foreign Direct Investment are among the mobilizing factors of the economic development of a country, alongside the domestic investments, being a basic support in the achievement of the development and modernization strategies. The study presents, briefly, the effects of intervening Foreign Direct Investment flows on the economy of a country, able, by the advanced experience brought, to generate a better capitalization of resources, a contribution to growth. The directions of manifesting the mechanisms of influence of Foreign Direct Investment, as well as the role that they hold for their impact, the economic environment of the host country and the policies practiced in relation to Foreign Direct Investment are taken into account. The purpose of the paper was to point out some aspects regarding the favourable impact that foreign investments could have on an economy, by the contribution to new technologies and the contribution to the productivity increase. The conclusions point to the potential of the impact of Foreign Direct Investment on development and the need for the host countries, to support some properly oriented policies, by maintaining a correlation between the volume of foreign investment flows and the development potential of a country. The research method used to carry out the study was the documentation from the foreign and domestic specialized literature, the synthesis and processing of the relevant ideas, by capturing the impact of Foreign Direct Investment in economic development.
\end{abstract}

Keywords:

impact, policies, development, foreign investments, effects

JEL Classification:

O10; F21; F23; F63

\section{Introduction}

The beneficial contribution expected to be obtained on the basis of foreign direct investments motivates the interest of host countries' governments in attracting them, the stake being the advantages of the investment flow for the economic growth.

Initially, considered as an important source of capital growth, especially, in the case of countries whose savings rates are modest, compared to the development needs of the economy, the prospects for appreciation of the role of foreign direct investments have changed over time.

In considering the positive effects of these, which place them among the important actions with role in the economic growth, the directions in which they are manifested were taken into account (te Velde D. W, 2006):

- $\quad$ it ensures the capital needed to supplement the public financing resources;

- it favours the increase of employment, by the new jobs created or by stimulating the activity of other firms in the local market; 
- $\quad$ alongside the capital flow, the contribution of foreign direct investments is embodied in advanced technologies, modern management practices used in the company in which they invest, which is also disseminated, in other firms with similar production, forced to adapt themselves under the pressure of competition;

- $\quad$ it bears the mark of stability on the long-term, the investor being interested in protecting and developing the investment.

Opinions regarding the appreciation of Foreign Direct Investment, as an important factor of economic and social development have led to the worldwide competition increase, for Foreign Direct Investment, their practice being considered a success.

The new approach of Foreign Direct Investment relates to growth, development and prosperity and, also, to the manifestation of economic freedom supported by appropriate mechanisms and institutions.

At the same time, also, there is the opinion that the excessive intervention of the multinationals may lead to the economic dependence of the host country, on the foreign capital and, also, to the danger of unbalancing the activity of the local companies, due to the competitive pressure exerted by the multinational companies (Horobeţ \& Popovici O., Şerbu, 2007).

\section{The role of Foreign Direct Investment in economic development}

In assessing the effects of Foreign Direct Investments on the economy of a country, a number of elements that can influence them must be taken into consideration (Horobet A. \& Popovici):

- the particularities of the sector in which the foreign investor acts;

- the time interval considered for the analysis of the impact;

- the type of investment implanted by the foreign company: greenfield, the merger with a local firm, acquisition etc. ;

- the strategy practiced by the investor;

- the attitude of the governments of the recipient countries towards Foreign

Direct Investment.

Foreign Direct Investment flows are profitable for the host countries for the contribution made for the use of resources (based on cost and efficiency criteria), the contribution to economic growth, the influence mechanisms manifesting in several directions (Trufin, 2016; Șerbu, 2007; te Velde D. W., 2006; Horobeţ \& Popovici, 2017):

- resources - capital;

- technological transfer;

- increasing the quality of human capital, acquiring new managerial skills;

- foreign trade (or access to the world market);

- competition;

- human resources development.

The accumulation of capital, by the contribution of foreign direct investments (alongside the own resources of the host country) is achieved to the extent in which the Foreign Direct Investment flows are intended for the investments financing and, implicitly, if the investors who have become owners, support the technological transfer (Șerbu S.-G., 2007).

Technological transfer The need to increase the economies of the host countries implies the sustained implementation of the new technologies, giving the measure of the influence of foreign direct investments. In the mechanism of technological transfer, the Findlay's (1978) theory concerning "the investment psychic distance" with reference to the distance between the higher level of development, in the country of 
origin of foreign direct investments and the lower level of the recipient country - in fact, technological distance - must be taken into account. The possibility of access to the new technologies is conditioned by the level of the other factors which get involved in supporting the investments of the foreign actor (human capital, infrastructure, distribution networks etc.), which can influence the type of technology that could be implemented.

The development potential is in inverse relation to the size of the technological distance between the investor and the local firms. The smaller this is, the more know-how information is more accessible to companies that use more advanced technologies, than to those that practice outdated production technologies and the qualification of the workforce is lower (Trufin O. S., 2016).

As regarding the transfer of technology from the investing companies to the local companies, the way is the imitation of the production process, a procedure frequently used in the transfer of the novelties from the fields of knowledge and technologies, with a beneficial influence on the productivity of the local companies. This acquisition technique is an adaptation of the new technology, conditioned by the complexity of the production process owned by the investor and by the real possibilities of implementation, of the host country (Trufin O. S., 2016). Thus, the technological transfer induced by Foreign Direct Investment contributes to the increase of industrial specialization, especially, in the advanced sectors of the receiving country.

The increase of the quality of human capital is ensured on the basis of the qualification of the personnel trained at the investor who, as a result of the transfer to the companies from the local market, bring their input of information in the field of management and of new technologies (Horobeț \& Popovici, 2017; Trufin, 2016, Șerbu, 2007).

Foreign trade, access of the products sell-out on the foreign market As a result of the transnational activity of Foreign Direct Investment, the host country has the advantage of increasing the export of goods based on the relations and investor access to international networks; thus, a transfer of production on the international market is carried out, which implies an increase of competitiveness, too. Therewith, the local companies have the opportunity to take over from transnational companies, the strategies for establishing the networks of distribution and international transport (Trufin, 2016, Șerbu, 2007).

It should be mentioned that the type of trade practiced by the receiving country influences the impact exerted by Foreign Direct Investment on the development (Trufin O. S., 2016):

- If the Foreign Direct Investment are planted in a country whose trade regime substitutes the import, the foreign companies will face the competition of the local companies, so they will have to reconsider their own technological advantages; for local firms, the chances of development are conditioned by classification in the rank of those with a less "technological distance" and have the possibility of technological transfer.

- In the event that the Foreign Direct Investment are located in a country that promotes the export, in order to increase the competitive advantages, the investors will have to focus, especially, on strengthening their own capacities of using the international markets and the distribution networks that they have and less, on obtaining the advantages at the expense of the production technologies.

Competition between the investing firms and local firms is a phenomenon of Foreign Direct Investment impact on the economies of the host countries. The competitive pressure exerted by the multinational companies entered on the local market, which have a competitive advantage, can cause the local companies to accelerate the implementation of the new technologies, such as to make their production more 
efficient, to increase the productivity and the chances of sustaining the competition (Trufin, 2016).

The development of human resources is manifested through (Șerbu, 2007):

- $\quad$ increasing employment due to the establishment of new companies that provide new jobs;

- employment, training and professional development in new fields, new qualifications and specializations.

As a rule, the impact of foreign direct investments on the economies in which they are planted is felt in two forms: direct and indirect (Horobeț \& Popovici, 2017).

- The direct impact is the consequence of the investments of the multinationals in new companies created in the host country or in companies that have been taken over from it and it manifests:

- at microeconomic level, through capital contribution, transfer of technologies and modern management skills, human resources development;

- by sectors of activity, contributing to change of the market structure and directing businesses towards meeting the demands of consumers and suppliers;

- at the macroeconomic level, the influence being felt on the increase of the budgetary revenues and in the export structure.

- The indirect impact is felt in the local companies, others than those that are the object of certain direct investments, but, involved under the pressure of the multinational companies competition, in taking over their advanced techniques, the consequence being an increase of their performance and competitiveness.

Schematically, the effects of foreign direct investments on the economies of the recipient countries and their forms of occurrence are presented in the figure below (Figure 1):

The effects of Foreign Direct Investment, both the direct and the indirect ones, are manifested in increasing companies performance, competitiveness and business efficiency.

The economic growth, as a result of the intervention of Foreign Direct Investment can be manifested (Figure 2) (te Velde D. W., 2006):

- for a short term, as a result of:

- increasing the volume of production or of accumulation of factors (growth, capital, employment etc.);

- the efficiency of using factors, by using higher technologies or localization in activity segments with higher added value;

- on a long term if they are associated with productivity spillover effects. 


\section{Foreign Direct Investment Impact}

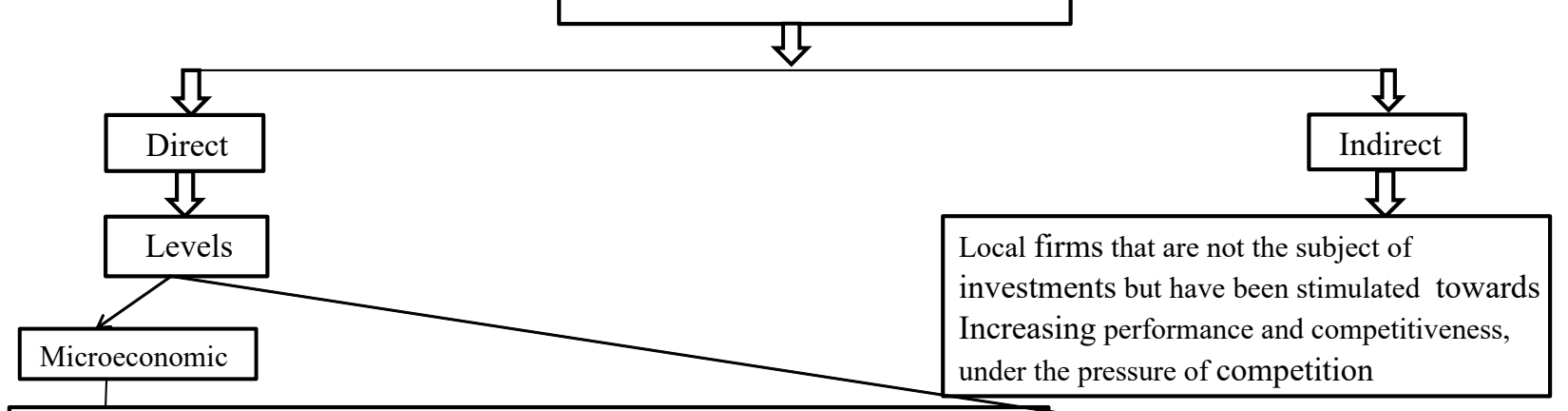

- capital contribution

- transfer of advanced technologies;

- increasing the quality of human capital, acquiring new competences and managerial techniques ;

- foreign trade - increasing export volume;

- competition- attracts the implementation of new technologies

- human resources development

- increasing business performance, competitiveness and efficiency;

- businessesmovement towards meeting the needs of consumers and suppliers.

Figure 1 The impact of foreign direct investments on the economies of the recipient countries and forms of occurrence

Source: author's processing based on information from bibliographic sources

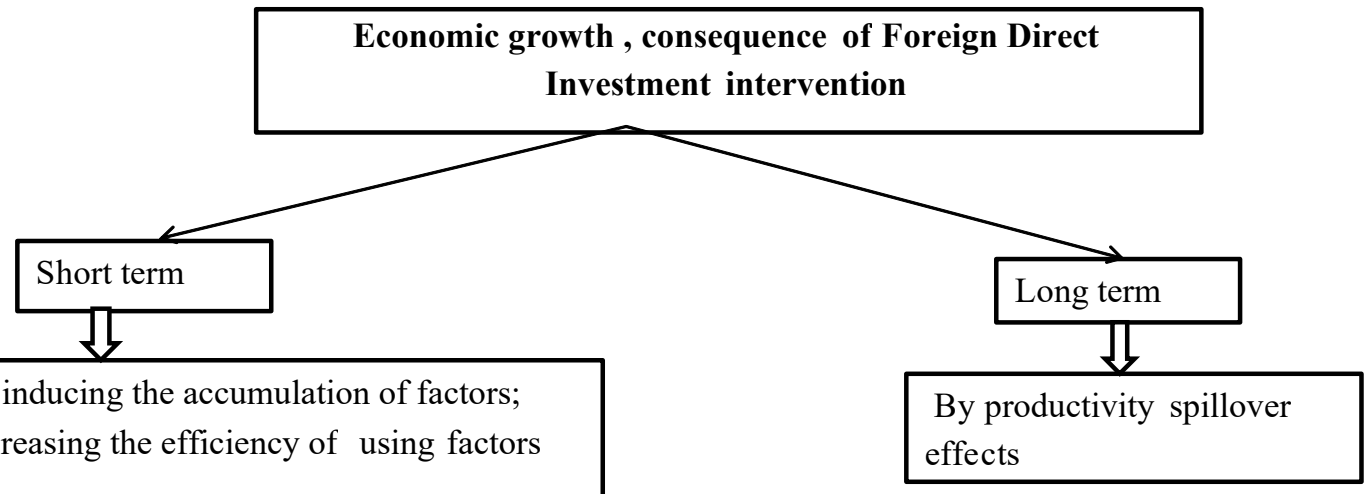

\section{Figure 2 Periods of manifestation of investment flows}

Source: author's processing based on information from Dirk Willem te Velde (2006), „Foreign Direct Investment and Development An historical perspective”, Background paper for 'World Economic and Social Survey for 2006; Overseas Development Institute, Commissioned by UNCTAD, 30 January 2006, https://www.odi.org/sites/odi.org.uk/files/odi-assets/publications-opinion-files/850.pdf 


\section{The relation - economic environment - impact of Foreign Direct Investment}

The contribution of Foreign Direct Investment to growth depends on the existence of a more developed economic environment and on the attitude of the host country, respectively, on the policies practiced by them, in relation to Foreign Direct Investment:

- trade policies - the extent to which they are favorable to export or, are oriented towards the internal market (te Velde D. W., 2006). According to analysts, the Foreign Direct Investment penetration is stronger in open economies towards this process than in the countries wherein the protectionist measures practiced are not favourable to foreign shares;

- the level of qualification of the human capital, the extent to which it is able to ensure the capitalization of the transfer of technology covered from the foreign subsidiaries to local companies (Șerbu S.-G., 2007);

- the governmental policies to support Foreign Direct Investment through taxation practiced or other forms of facilities (Trufin O. S., 2016, p. 71);

- macroeconomic policies of the host state, in fields such as infrastructure, monetary policy (Trufin O. S., 2016);

- the level of development of the financial markets, on the functioning of which, the creation of relations between the national investor and the foreign one depends on (Serbu, 2007);

- the type of investment flow, the characteristic of the intervention may influence, differently, the effects of Foreign Direct Investment on the development of a country's economy. For example, the "greenfield" Foreign Direct Investment impact on the economy is beneficial, as it develops new capacities, favouring the employment and consumption. Differently, the acquisitions may have some adverse effects, among consequences, being possible the withdrawal of some activities and jobs respectively (Șerbu, 2007).

By the impact produced, the Foreign Direct Investment signifies a real potential for the economic development, the increase of the competitiveness and the performances of the host country companies.

At the macroeconomic level, the impact of the foreign investments flow can be positive but also, negative, depending on the type of Foreign Direct Investment implanted, the economic policies and the conditions offered by the receiving country.

There are some critical opinions referring to the impact of Foreign Direct Investment and the risks that their intervention it supposes, such as (Șerbu, 2007, Trufin, 2016, Horobeţ \& Popovici, 2017):

- the interest of the multinationals to invest in high productivity fields, without favouring the increase of the productivity of the national companies;

- the effect of foreign competition leads to a diminution of the market segment of the national investors and, respectively, of their profitability, with effects in the decrease of the productivity;

- on the local market, it occurs a transfer of the demand from the local companies to the multinational companies, whose marginal costs are lower, due to the use of advanced technologies,; in the short term, local firms are disadvantaged because, in order to resist competition, they must adopt new technologies and increase productivity but, in the long term, they have the prospect of development;

- "technological distance" can produce favourable effects in localization of foreign direct investments on the market of the host country, materialized in the increase of the productivity, of the commercial flows, but at the same time, it can lead to the decrease of the number of jobs, as an effect of the productivity increase; 
- the activity of local companies can be unbalanced due to the competitive pressure exerted by the multinational companies;

- there is the risk of losing the position held on the market by the local companies, sometimes, even the elimination of the local producers, situation generated by the advanced technology and the resources owned by the foreign investor.

In this context, the host country can orient itself towards the practice of a strategy whereby the flows of foreign direct investments should be directed towards areas and sectors of activity in which there are the premises of optimizing the positive effects, with the least possible manifestation of the negative ones (Horobeț \& Popovici, 2017). The policies initiated by this can be of sustaining the Foreign Direct Investment, but also, of discouraging, the orientation being, depending on their influence on the local companies (Trufin, 2016).

In the context of the beneficial role of the intervention of foreign direct investments in an economy, it is worth mentioning, also, the fact that the excessive intervention of the multinationals, in the economic activity of a country, can determine the economic dependence of the receiving country, on the foreign capital (Horobeț \& Popovici, 2017).

\section{Conclusions}

The approach of foreign direct investments relates to economic growth and development, to prosperity. The impact of foreign direct investments on growth and development is determined by the type of Foreign Direct Investment, the particularities of the company, the economic conditions in the area whereat the investments and commercial policies are implemented (Trufin, 2016, Negrițoiu 1996).

Of particular importance is training of human resources, as well as the construction of technological capabilities, that should favour the processing of spillover effects of productivity (te Velde, 2006).

By the interaction with Foreign Direct Investment, the host country's companies have the possibility of knowledge of new techniques of production and management, of increasing the productivity, entering and expanding the business on the international market (Trufin O. S., 2016).

Foreign Direct Investment is constituted as an important element for the economic development and the increase of the competitiveness of the beneficiary countries; at the same time, some aspects of risk, such as: changes in the structure of the business environment, loss of market position of local firms, or removal of local producers, generated by foreign competition, must also be taken into account (Horobeț \& Popovici, 2017).

The policies supported by the governments of the host countries can be oriented according to the interests of the national economies, respectively:

- $\quad$ supporting the attraction of Foreign Direct Investment or discouragement, depending on the influences they can induce on local companies (Trufin, 2016);

- $\quad$ orienting, as far as possible, of the external investment flow, towards sectors or areas of activity that have the perspective of manifesting the positive consequences of the impact and, respectively, as low as possible, of the negative ones (Horobeț \& Popovici, 2017; Șerbu, 2007);

- attracting those types of investments that favour economic growth, "efficiency-seeking" şi and "greenfields" and to a lesser extent, of those of mergers and acquisitions type (Șerbu, 2007).

It should not be neglected the fact that, for the positive effects of foreign direct investments on growth, the host country must be at an appropriate level of economic 
development, able of taking over the transfer of technology, information, qualification, with effects on productivity growth (Horobeţ \& Popovici, 2017; Șerbu, 2007, Trufin, 2016).

Acknowledgment: The study is a part of the research paper of the Institute of National Economy, Romanian Academy, "Investiţiile străine directe şi impactul schemelor de parteneriat public-privat. Studiu de caz România”, achieved in 2019, by PhD. Florina Popa (Coordinator).

\section{References}

Aitken, B.; Gordon H. Hanson; Harrison, Ann, E., (1997), "Spillovers, Foreign Investment and Export Behavior", Journal of International Economics, 43: 103132 , issue $1-2$;

Balasubramanyam, V. N.; Salisu, M.; Sapsford D. (1996), "Foreign Direct Investment and Growth in EP and IS Countries", The Economic Journal, Vol. 106, No. 434 (Jan., 1996), pp. 92-105, Published by: Oxford University Press on behalf of the Royal Economic Society, DOI: 10.2307/2234933, https://www.jstor.org/stable/2234933;

Findlay, R. (1978), „Relative Backwardness, Direct Foreign Investment and the Transfer of Technology: A Simple Dynamic Model", The Quarterly Journal of Economics, Vol. 92, No. 1 (Feb., 1978), pp. 1-16, Published by: Oxford University Press, DOI: 10.2307/1885996, https://www.jstor.org/stable/1885996;

Görg, H.; Greenaway, D. (2003) „Much Ado about Nothing ? Do Domestic Firms Really Benefit from Foreign Direct Investment?", Discution Paper, 944, November, 2003, http://ftp.iza.org/dp944.pdf;

Haaparanta (1996), "Competition of FDI", Journal of Public Economics, 71: 121-139; Horobeţ, A.; Popovici, O. (2017), Investiţiile Străine Directe: Evoluţia şi importanţa lor în România, Mai 2017, Studiu realizat în parteneriat de Academia de Studii Economice Bucureşti şi Consiliul Investitorilor Străini, https://fic.ro/Documents/view/Studiu-Investitiile-straine-directe-evolutia-siimportanta-lor-in-Romania;

Mirza, H. and Giroud A. (2004), 'Regionalization, Foreign Direct Investment and Poverty Reduction. Lessons From Vietnam In ASEAN', Journal of the Asia $\begin{array}{lllll}\text { Pacific Economy } & 9 & \text { (2), } & \text { pp. } & \text { 223-248, }\end{array}$ https://doi.org/10.1080/1354786042000207353;

Negriţoiu. M. (1996), SALT ÎNAINTE. Dezvoltarea şi Investiţiile Străine Directe. (JUMPING AHEAD. Foreign Direct Investments and the economic development), Ediţie îngrijită de Valeriu Ioan-Franc, Editura PRO \& Editura Expert, Bucureşti;

Şerbu Simona-G. (2007), Investiţiile Străine Directe. Determinanţi, Efecte şi Politici de Promovare, Casa Cărţii de Ştiinţă, Cluj-Napoca;

te Velde, Dirk, Willem (2006), „Foreign Direct Investment and Development An historical perspective", Background paper for "World Economic and Social Survey for 2006', Overseas Development Institute, Commissioned by UNCTAD, 30 January 2006, https://www.odi.org/sites/odi.org.uk/files/odiassets/publications-opinion-files/850.pdf;

Trufin Ovidiu S. (2016) Investiţile Străine Directe. Procesul de Dezvoltare Investiţională (PDI) în România, Editura Tehnopress, Iaşi;

Voinea L. (2007), Corporațiile transnaționale și capitalismul global, Editura Polirom, Iași; 
SOME ASPECTS REGARDING THE IMPACT OF FOREIGN DIRECT INVESTMENT IN ECONOMIC DEVELOPMENT UNCTAD (1999), World Investment Report, UNCTAD, Geneva. 